\title{
Boradiazaindacene (Bodipy)-based building blocks for the construction of energy transfer cassettes
}

\author{
Gokhan Barin ${ }^{\text {a }}$, M. Deniz Yilmaz ${ }^{\mathrm{b}}$, Engin U. Akkaya a,* \\ a UNAM-Institute of Materials Science and Nanotechnology and Department of Chemistry, Bilkent University, Ankara, TR-06800, Turkey \\ ${ }^{\mathrm{b}}$ Department of Chemistry, Middle East Technical University, Ankara, TR-06531, Turkey
}

\section{A R T I C L E I N F O}

\section{Article history:}

Received 9 December 2008

Revised 16 January 2009

Accepted 28 January 2009

Available online 1 February 2009

\begin{abstract}
A B S T R A C T
Energy transfer cassettes composed entirely of boradiazaindacene (Bodipy) units were designed and synthesized to capture photonic energy and convert it to longer wavelength fluorescence emission. The new energy transfer systems obtained by simple condensation reactions are capable of elaborating efficient energy transfer from donor Bodipy units to the distyryl-Bodipy acceptor.
\end{abstract}

(c) 2009 Elsevier Ltd. All rights reserved.
In the past two decades, much attention has been focused on the design and synthesis of molecular and supramolecular systems which can eventually function as light harvesting antennae in artificial systems for the photochemical conversion of solar energy. ${ }^{1}$ In multichromophoric energy transfer cassettes, one of the chromophores is excited by the absorption of a photon of light, and energy transfer can occur when the donor returns to its ground state simultaneously with raising of the acceptor to its excited state. ${ }^{2}$

Excitation energy transfer (EET) can take place essentially via two pathways: (i) through bond (Dexter mechanism) ${ }^{3}$ and (ii) through space (Förster mechanism). ${ }^{4}$ The former is a non-radiative energy transfer from a donor to an acceptor, which are connected by a conjugated bond. The latter, on the other hand, requires strong overlap between the emission spectrum of the donor and absorption of the acceptor. Experimentally, the most convenient method for the preparation of such systems is when the donor and acceptor components are brought together as a single unit in an energy transfer cassette. ${ }^{5}$

Boradiazaindacenes (Bodipy dyes) ${ }^{6}$ have been studied extensively as building blocks of energy transfer cassettes, ${ }^{7}$ artificial light harvesting complexes ${ }^{8}$ and as sensitizers for dye sensitized solar cells. ${ }^{9}$ In this report, we describe the design, synthesis and spectroscopic properties of new energy transfer cassettes based entirely on differentially functionalized boradiazaindacene (Bodipy) dyes.

The structures of compounds $\mathbf{4 , 7}$ and $\mathbf{9}$ are shown in Scheme 1. In order to access the cassettes synthetically, singly protected terephthaldehyde $\mathbf{1}$ was prepared and condensed with 3-ethyl2,4-dimethylpyrrole and was then treated with boron trifluoridediethyl etherate to give compound 2 . Condensation of $\mathbf{2}$ with $p$-tolualdehyde, followed by acidic deprotection of the crude compound gave distyryl-Bodipy ${ }^{10}$ derivative 3 . The terminal

\footnotetext{
* Corresponding author. Tel.: +90 312290 2450; fax: +90 3122664068

E-mail address: eua@fen.bilkent.edu.tr (E.U. Akkaya).
}

aldehyde of $\mathbf{3}$ was reacted with 3-ethyl-2,4-dimethylpyrrole to yield cassette 4 . Similar condensation reactions were pursued in order to obtain cassettes $\mathbf{7}$ and $\mathbf{9}$ (Scheme 1). The structures of all new compounds including 4, 7 and 9 were confirmed by ${ }^{1} \mathrm{H}$ NMR, ${ }^{13} \mathrm{C}$ NMR and HRMS (Supplementary data). The absorption spectra of the three bichromophoric species $(\mathbf{4}, \mathbf{7}$ and $\mathbf{9})$ are presented in Figure 1, which are normalized to $650 \mathrm{~nm}$, the peak absorption wavelength $\left(\lambda_{\max }\right)$ of the distyryl-Bodipy core. As expected, the absorption spectra of compounds 4,7 and 9 are composites of donor and acceptor spectra, with the band at $520 \mathrm{~nm}$ arising from the donor chromophore and the band at $650 \mathrm{~nm}$ originating from the acceptor chromophore. At equal concentrations, the absorbance at $520 \mathrm{~nm}$, the peak absorption wavelength $\left(\lambda_{\max }\right)$ of the Bodipy donor, increases with increasing number of donor chromophores.

The emission spectra of compounds 4,7 and 9 are shown in Figure 2. Excitation of the donor chromophore at $525 \mathrm{~nm}$ results in a strong emission from the acceptor at $670 \mathrm{~nm}$. The spectral overlap between the donor emission peak and the absorption peak of the distyryl-Bodipy chromophore is apparent when Figures 1 and 2 are inspected carefully. For comparison, an overlay of these two normalized peaks is given in the supporting information. Excitation spectra (Figure 3) provide further evidence for the energy transfer. The spectra obtained by collecting emission data at $670 \mathrm{~nm}$ show two peaks, one for the shorter wavelength chromophore and other for the distyryl chromophore. As the number of light harvesting Bodipy chromophores around the distyryl-substituted Bodipy increases, the excitation peak around $525 \mathrm{~nm}$ becomes more prominent, a clear indication of efficient light harvesting and energy transfer. The energy transfer should be mostly through space because individual peaks clearly correspond to those in the model Bodipy and distyryl-Bodipy compounds, and the 1,7-dimethyl groups on the Bodipy core place the peripheral Bodipy chromophore orthogonal to the core, thus essentially breaking the conjugation between the bodipy units. The photo- 

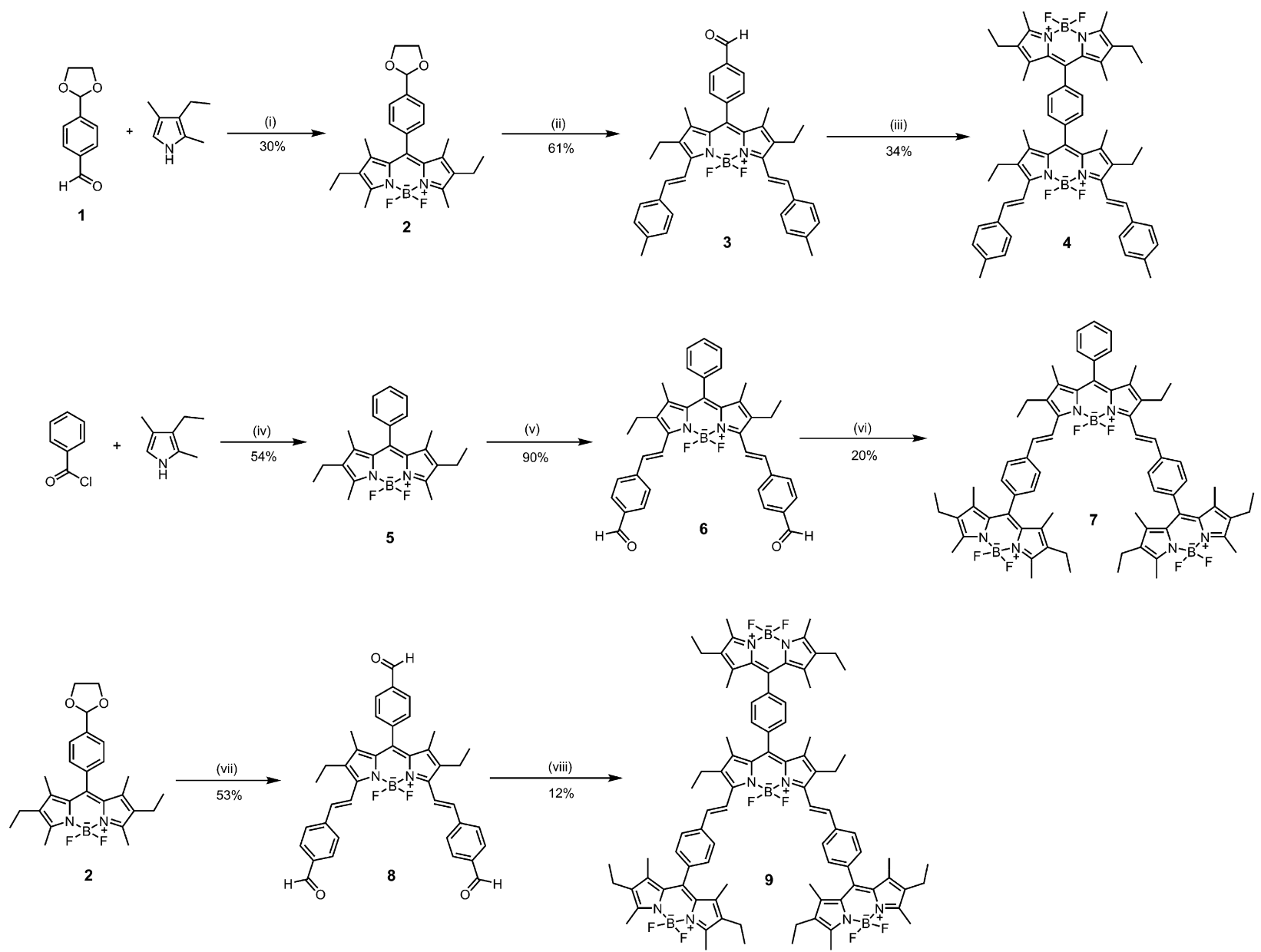

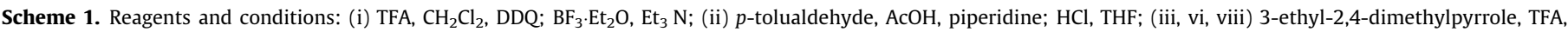
$\mathrm{CH}_{2} \mathrm{Cl}_{2}, \mathrm{DDQ} ; \mathrm{BF}_{3} \cdot \mathrm{Et}_{2} \mathrm{O}, \mathrm{Et}_{3} \mathrm{~N}$ (iv) $\mathrm{BF}_{3} \cdot \mathrm{Et}_{2} \mathrm{O}, \mathrm{Et}_{3} \mathrm{~N}$; (v) 1, AcOH, piperidine; $\mathrm{HCl}, \mathrm{THF}$.

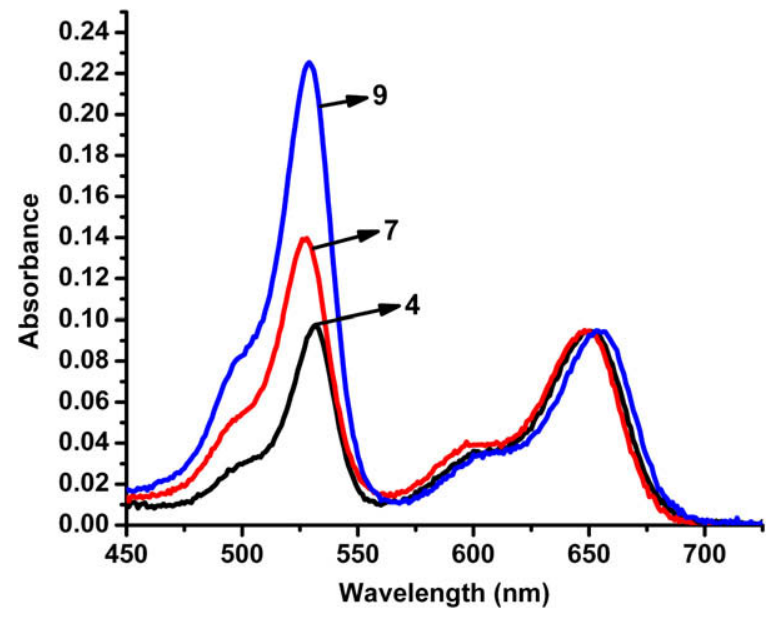

Figure 1. Absorption spectra of $\mathbf{4 , 7}$ and $\mathbf{9}$ in chloroform at room temperature. The spectra of $\mathbf{4}$ and $\mathbf{7}$ are normalized with respect to the spectrum of $\mathbf{9}$ at $670 \mathrm{~nm}$. The concentration of the cassettes is adjusted so that all three compounds have equal absorbance values at $650 \mathrm{~nm}$, which brings their concentration to an approximate value of $1.3 \times 10^{-6} \mathrm{M}$ for all three compounds.

physical properties of Bodipy compounds $2-\mathbf{4}$ and $\mathbf{6 - 9}$ are listed in Table 1.

Thus, in this work, we have demonstrated the utility of Bodipy chemistry in the straightforward design and synthesis of energy

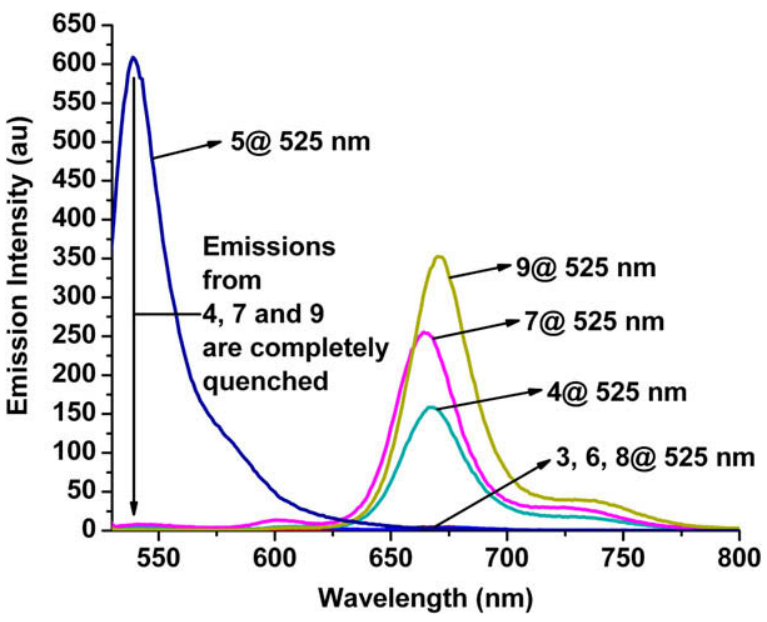

Figure 2. The fluorescence spectra of 4,7 and 9 in chloroform at room temperature. Excitation wavelengths are as indicated for each spectrum.

transfer cassettes and light harvesting systems. Since large absorption cross-sections in the visible region are accessible in this manner, in the near future, it should not be surprising to find similar designs with multiple differentially functionalized Bodipy units for light harvesting or cascade systems exploiting the versatility of Bodipy dyes. 


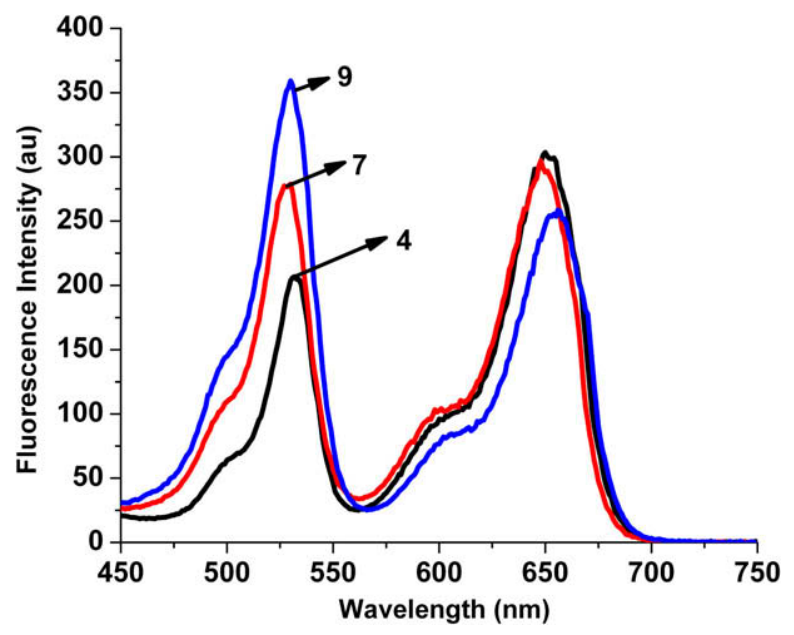

Figure 3. The excitation spectra of 4,7 and $\mathbf{9}$ in chloroform. The emission data were collected at $670 \mathrm{~nm}$. Concentrations of the energy transfer cassettes are adjusted so that all three compounds have equal absorbance values at $650 \mathrm{~nm}$, which brings their concentration to an approximate value of $1.3 \times 10^{-6} \mathrm{M}$ for all three compounds.

Table 1

Photophysical Properties of Bodipy compounds in $\mathrm{CHCl}_{3}$

\begin{tabular}{lllll}
\hline Compound & $\begin{array}{l}\varepsilon\left(\lambda_{\max }\right) /\left(\mathrm{M}^{-1} \mathrm{~cm}^{-1}\right) \\
(\mathrm{nm})\end{array}$ & $\begin{array}{l}\lambda_{\mathrm{em}} \\
(\mathrm{nm})\end{array}$ & $\begin{array}{l}\Phi_{\mathrm{F}} \\
\left(\lambda_{\mathrm{ex}}=525 \mathrm{~nm}\right)\end{array}$ & $\begin{array}{l}\Phi_{\mathrm{F}} \\
\left(\lambda_{\mathrm{ex}}=645 \mathrm{~nm}\right)\end{array}$ \\
\hline $\mathbf{2}$ & $79922(528)$ & 539 & 0.61 & - \\
$\mathbf{3}$ & $81374(649)$ & 667 & 0.18 & - \\
$\mathbf{6}$ & $61830(656)$ & 675 & 0.18 & - \\
$\mathbf{8}$ & $62237(660)$ & 676 & 0.21 & - \\
$\mathbf{4}$ & $72073(527), 71128$ & 668 & 0.24 & 0.33 \\
$\mathbf{7}$ & $(651)$ & & & \\
& $114880(528), 77478$ & 664 & 0.24 & 0.33 \\
$\mathbf{9}$ & $(649)$ & & & 0.31 \\
& $191746(529), 80497$ & 670 & 0.22 & \\
\hline & $(654)$ & & & \\
\end{tabular}

\section{Acknowledgements}

This work was supported by the Turkish Scientific and Technical Research Council (TUBITAK) and Turkish Academy of Sciences (TUBA). GB thanks TUBITAK for a scholarship.

\section{Supplementary data}

Supplementary data associated with this article can be found, in the online version, at doi:10.1016/j.tetlet.2009.01.141.

\section{References and notes}

1. Balzani, V.; Credi, A.; Venturi, M. Molecular Devices and Machines: A Journey into the Nanoworld; Wiley-VCH: Weinheim, Germany, 2003.

2. Turro, N. J. Modern Molecular Photochemistry; University Science Books: Sausalito, 1991.

3. Dexter, D. L. J. Chem. Phys. 1953, 21, 836

4. (a) Förster, T. Ann. Phys. 1948, 2, 55; (b) Förster, T. Z. Naturforsch 1949, 4, 321.

5. Lee, L. G.; Spurgeon, S. L.; Heiner, C. R.; Benson, S. C.; Rosenblum, B. B.; Menchen, S. M.; Graham, R. J.; Constantinescu, A.; Upadhya, K. G.; Cassel, J. M. Nucleic Acids Res. 1997, 25, 2816.

6. Recent reviews: (a) Ulrich, G.; Ziessel, R.; Harriman, A. Angew. Chem., Int. Ed. 2008, 47, 1184; (b) Ziessel, R. Comput. Rend. Chim. 2007, 10, 622; (c) Loudet, A. Burgess, K. Chem. Rev. 2007, 107, 4891.

7. (a) Burghart, A.; Thoresen, L. H.; Chen, J.; Burgess, K.; Bergström, F.; Johansson, L. B.-Å. Chem. Commun. 2000, 2203; (b) Goze, C.; Ulrich, G.; Ziessel, R. Org. Lett. 2006, 8, 4445; (c) Wan, C.-W.; Burghart, A.; Chen, J.; Bergström, F.; Johansson, L. B.-Å.; Wolford, M. F.; Kim, T. G.; Topp, M. R.; Hochstrasser, R. M.; Burgess, K. Chem. Eur.J. 2003, 9, 4430; (d) Lammi, R. K.; Wagner, R. W.; Ambroise, A.; Diers, J. R.; Bocian, D. F.; Holten, D.; Lindsey, J. S. J. Phys. Chem. B 2001, 105, 5341; (e) Harriman, A.; Izzet, G.; Ziessel, R. J. Am. Chem. Soc. 2006, 128, 10231; (f) Zhou, Y.; Xiao, Y.; Chi, S.; Qian, X. Org. Lett. 2008, 10, 633; (g) Zhang, X.; Xiao, Y.; Qian, X. Org. Lett. 2008, 10, 29; (h) Coskun, A.; Akkaya, E. U. J. Am. Chem. Soc. 2005 127, 10464; (i) Coskun, A.; Akkaya, E. U. J. Am. Chem. Soc. 2006, 128, 14474

8. (a) Yilmaz, M. D.; Bozdemir, O. A.; Akkaya, E. U. Org. Lett. 2006, 8, 2871; (b) Goeb, S.; Ziessel, R. Org. Lett. 2007, 9, 737; (c) D’Souza, F.; Smith, P. M.; Zandler M. E.; McCarthy, A. L.; Itou, M.; Araki, Y.; Ito, O. J. Am. Chem. Soc. 2004, 126 7898.

9. Erten-Ela, S.; Yilmaz, M. D.; Icli, B.; Dede, Y.; Icli, S.; Akkaya, E. U. Org. Lett. 2008 $10,3299$.

10. (a) Dost, Z.; Atigan, S.; Akkaya, E. U. Tetrahedron 2006, 62, 8484; (b) Saki, N.; Dinc, T.; Akkaya, E. U. Tetrahedron 2006, 62, 2721. 